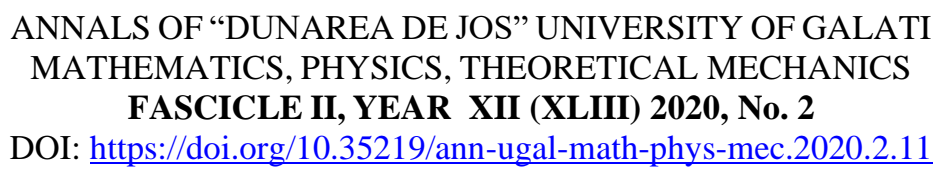

\title{
Noise: a risk factor for sailors' health and navigation safety
}

\author{
Mihaela Picu, Laurentiu Picu \\ "Dunarea de Jos" University of Galati, Faculty of Engineering and Agronomy Braila, 800008 Galati, Romania \\ Corresponding author: mihaelapicu@yahoo.com
}

\begin{abstract}
Occupational noise affects the health of sailors. Following health checks, it was found that almost a quarter of a pusher's navigating crew lost their hearing in a proportion of 10-40\%. For this reason, determinations were made to see which are the most important sources of noise. These determinations showed that the noise in the engine room exceeds $90-100 \mathrm{~dB}$, and in the control cabin, the sound level is $75-80 \mathrm{~dB}$. Noise also impedes communication between sailors, making it extremely dangerous for the safety of people and vessels. For these reasons, companies must take all measures to ensure that the work of seafarers does not affect their health and it runs safely.
\end{abstract}

Keywords: noise, sailors, health, navigation safety

\section{INTRODUCTION}

Noise at work is a general problem around the world. The European Union reports that onethird of the total registered occupational diseases represent hearing loss caused by noise; for this reason, several rules have been developed, of which the most important is Directive 2003/10/EC of the European Parliament and of the Council of 6 February 2003 on the minimum health and safety requirements regarding the exposure of workers to the risks arising from physical agents (noise) [1].

"For the purposes of this Directive the exposure limit values and exposure action values in respect of the daily noise exposure levels and peak sound pressure are fixed at:

(a) exposure limit values: $\mathrm{L}_{\mathrm{EX}, 8 \mathrm{~h}}=87 \mathrm{~dB}(\mathrm{~A})$ and $\mathrm{p}_{\text {peak }}=200 \mathrm{~Pa}$ respectively;

(b) upper exposure action values: $\mathrm{L}_{\mathrm{EX}, 8 \mathrm{~h}}=85 \mathrm{~B}(\mathrm{~A})$ and $\mathrm{p}_{\text {peak }}=140 \mathrm{~Pa}$ respectively;

(c) lower exposure action values: $\mathrm{L}_{\mathrm{EX}, 8 \mathrm{~h}}=80 \mathrm{~dB}(\mathrm{~A})$ and peak $=112 \mathrm{~Pa}$ respectively." [1]

The purpose of these stipulations is to reduce noise, especially at the source, but also by using hearing protection equipment.

An example of a job where employees work in a noisy environment is on board ships. There are many studies that have analysed these aspects for sailors on sea or ocean vessels [2], [3], [4], [5], [6] but only a few for ships operating on the Danube [7], [8], [9]. This Directive was subsequently supplemented by Directive (EU) 2016/1629 [10] which stipulates: "Article 8.10 (Noise emitted by vessels): 2 . The noise generated by a vessel under way shall not exceed $75 \mathrm{~dB}(\mathrm{~A})$ at a lateral distance of $25 \mathrm{~m}$ from the ship's side and 3. Apart from transhipment operations, the noise generated by a stationary vessel shall not exceed $65 \mathrm{~dB}(\mathrm{~A})$ at a lateral distance of $25 \mathrm{~m}$ from the ship's side" and "Article 11.09 (Protection against noise and vibration): 2. Permanent working spaces shall, in addition, be so constructed and soundproofed that the health and safety of crew members are not affected by noise, and 3. For crew members who are likely to be exposed to noise levels exceeding $85 \mathrm{~dB}(\mathrm{~A})$ every day individual acoustic protection devices shall be available." Also, chapter 3 "Noise measurements" are presented the rules for measuring sound level on a ship: "3.1. On board craft Measurements shall be carried out in accordance with ISO 2923:2003 and air noise emitted from the craft in accordance with EN ISO 2922:2000". 
Inland navigation standards were subsequently developed [11], [12]. "Originating in Germany, the Danube flows southeast for $2850 \mathrm{~km}$, passing through or bordering Austria, Slovakia, Hungary, Croatia, Serbia, Romania, Bulgaria, Moldova, and Ukraine before draining into the Black Sea. Its drainage basin extends into nine more countries." https://en.wikipedia.org/wiki/Danube

Given the regulations of the European Union, it should be noted that Slovakia and Hungary joined on 1 May 2004, Serbia, Romania, and Bulgaria on 1 January 2007, Croatia on 1 July 2013, therefore they must comply with the guidelines of EU Directive 2016/1629 [10]. The Republic of Moldova and Ukraine are not members of the EU.

The purpose of this paper is to analyse the noise in the engine room and in the control cabin of a pusher on the Danube.

\section{EXPERIMENTAL}

The determinations took place between Galați ( $\mathrm{km} \mathrm{150)}$ and Giurgiu (km 493), in February 2019. The weather conditions were difficult, with snow, low temperatures $\left(-2-0^{\circ} \mathrm{C}\right.$ by night and $0-4^{\circ} \mathrm{C}$ by day), wind speed of 30-45 km/h, and normal atmospheric pressure.

The determinations were made with the Blue Solo 01dB sound level meter (Fig. 1), according to IEC 61672-1:2002 [13] and the analysis was done with the dBFA 3.2 Software.

During this period, were calculated: Daily noise exposure (LEP,d), Exposure points (job/task) and Exposure points per hour with Noise: Exposure Calculator-HSE for three situations: ship starts from the shore, ship's running and mooring manoeuvre and idle with the generator.

The crew consisted of 6 people: 1 captain, 1 coxswain, 2 mechanics, 2 sailors (Table 1). Measurements were made in parallel inside the engine room and in the command room.

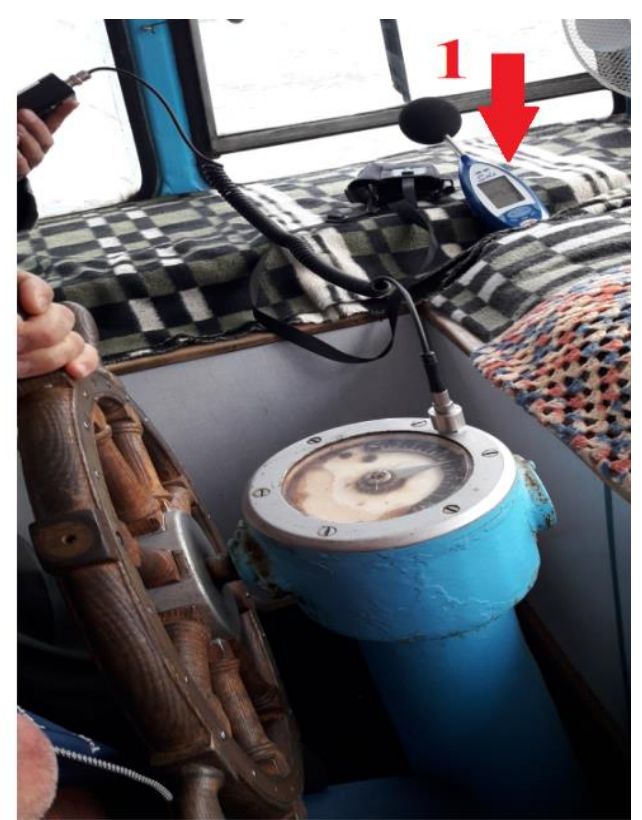

Fig. 1. Measurements in the engine room (1) - Sonometer Blue Solo

Table 1. Subject's features

\begin{tabular}{|c|c|c|c|c|c|c|c|}
\hline Subject & BMI & $\begin{array}{c}\text { Age } \\
\text { (years) }\end{array}$ & Smoker & Drinkers* & $\begin{array}{c}\text { Seniority } \\
\text { (years) }\end{array}$ & $\begin{array}{c}\text { Cardiovascular } \\
\text { problems }\end{array}$ & $\begin{array}{c}\text { Personal } \\
\text { problems }\end{array}$ \\
\hline 1- captain & 30,2 & 51 & - & Yes & 28 & - & $\mathrm{x}$ \\
\hline 2- coxswain & 26,4 & 49 & Yes & Yes & 30 & $\mathrm{x}$ & $\mathrm{x}$ \\
\hline 3- mechanic & 25,8 & 50 & Yes & Yes & 31 & $\mathrm{x}$ & $\mathrm{x}$ \\
\hline 4- mechanic & 32,4 & 44 & Yes & Yes & 14 & $\mathrm{x}$ & $\mathrm{x}$ \\
\hline 5- sailor & 24,8 & 53 & Yes & Yes & 22 & $\mathrm{x}$ & $\mathrm{x}$ \\
\hline 6- sailor & 24,5 & 56 & Yes & Yes & 33 & $\mathrm{x}$ & $\mathrm{x}$ \\
\hline
\end{tabular}

Overweight $=25-29.9 \mathrm{BMI}$; Obesity $=30 \mathrm{BMI}$ or greater

*More than 2 glasses of wine/day

\section{RESULTS AND DISCUSSION}

The measurements were made for the two mechanics (inside the engine room) and for the captain and the coxswain (inside the command room). 


\subsection{Measurements in the engine room}

Inside the engine room, determinations were made for the 2 mechanics in three cases: the ship leaves the shore, the ship is running, and mooring manoeuvre.

Frequency-based noise analyses, for each case, are shown in Figs. 2-4. The minimum cursor was set to $16 \mathrm{~Hz}$, and the maximum to $125 \mathrm{~Hz}$.

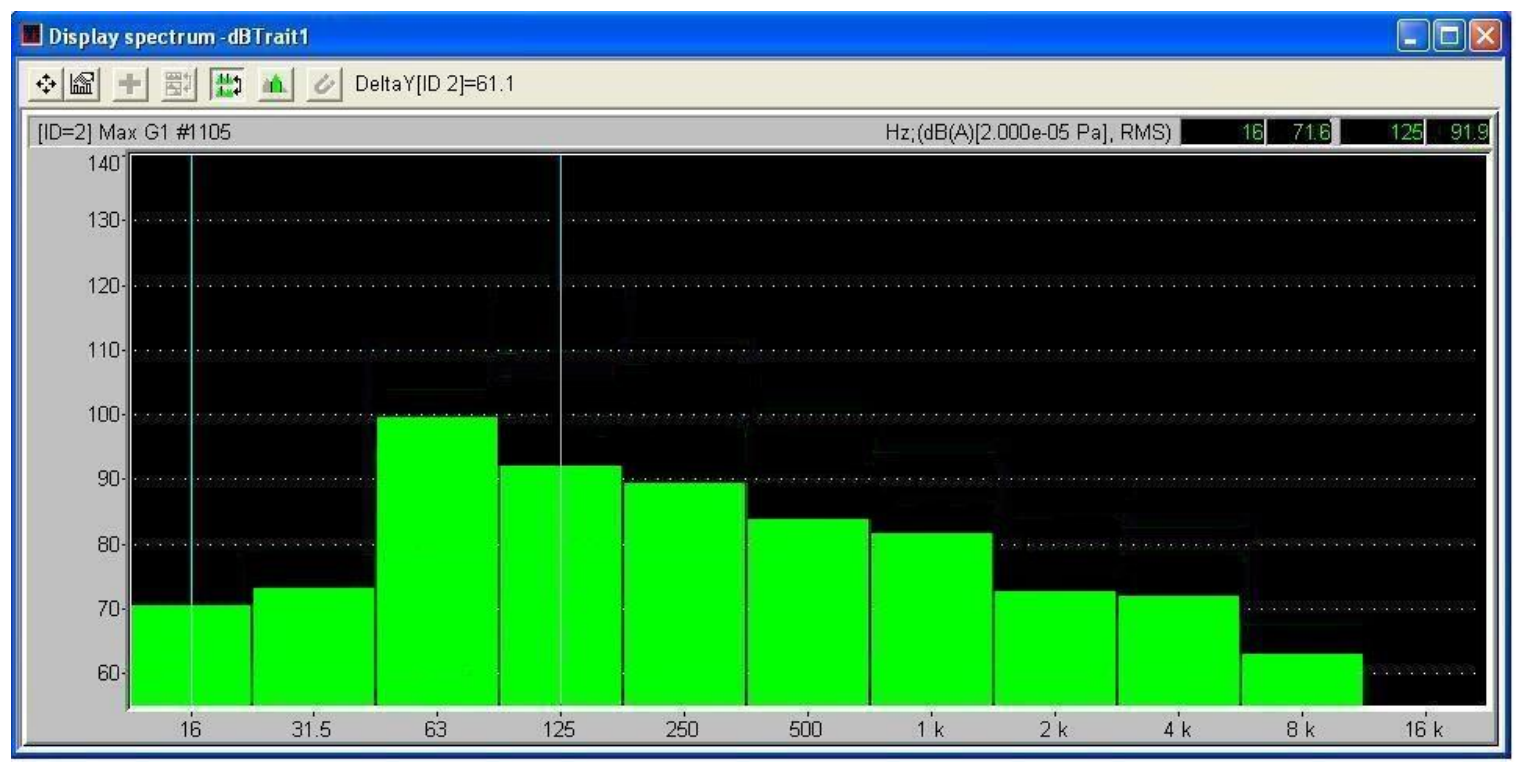

Fig. 2. Evaluation of noise in the engine room when ship leaves the shore

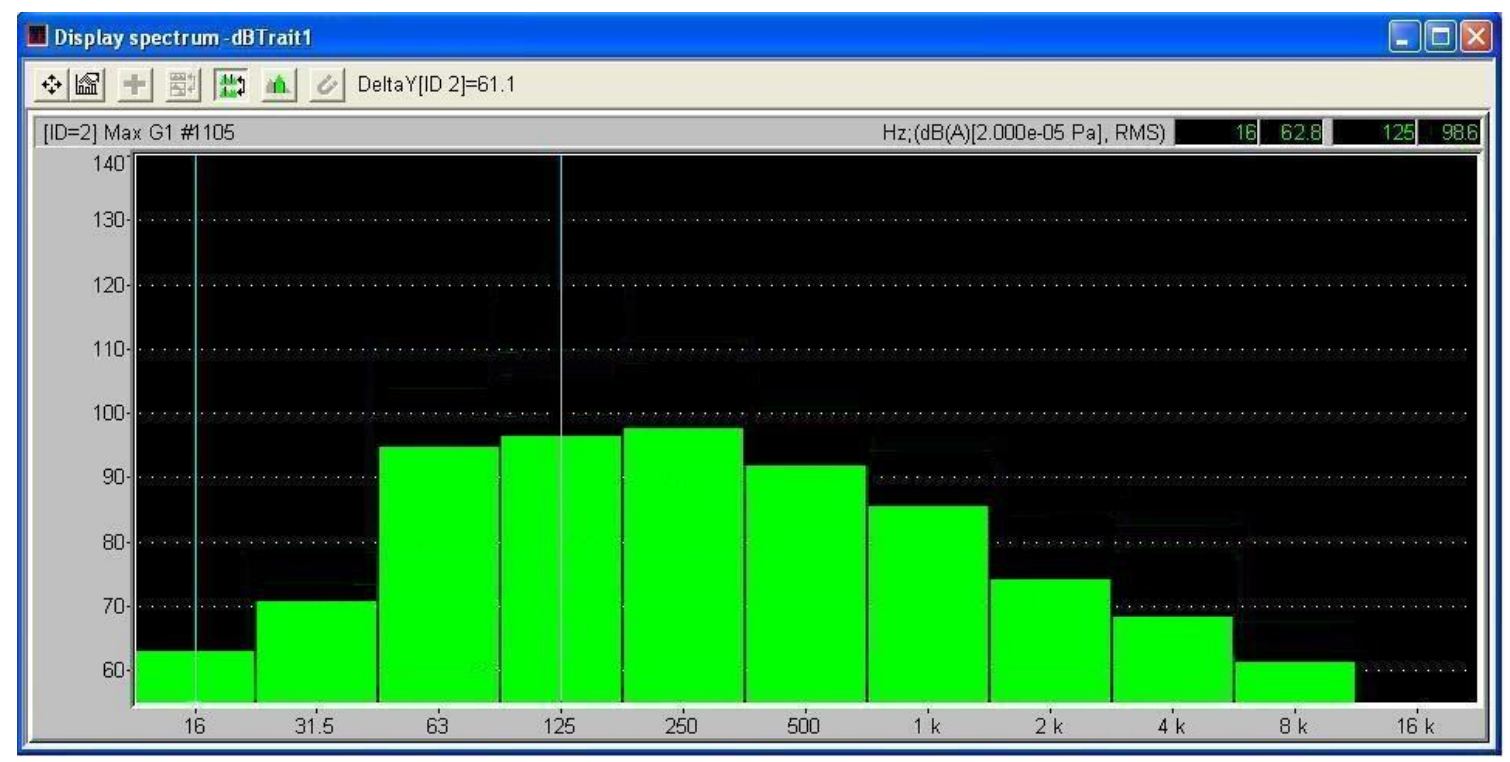

Fig. 3. Evaluation of noise in the engine room when the ship executes mooring manoeuvre 


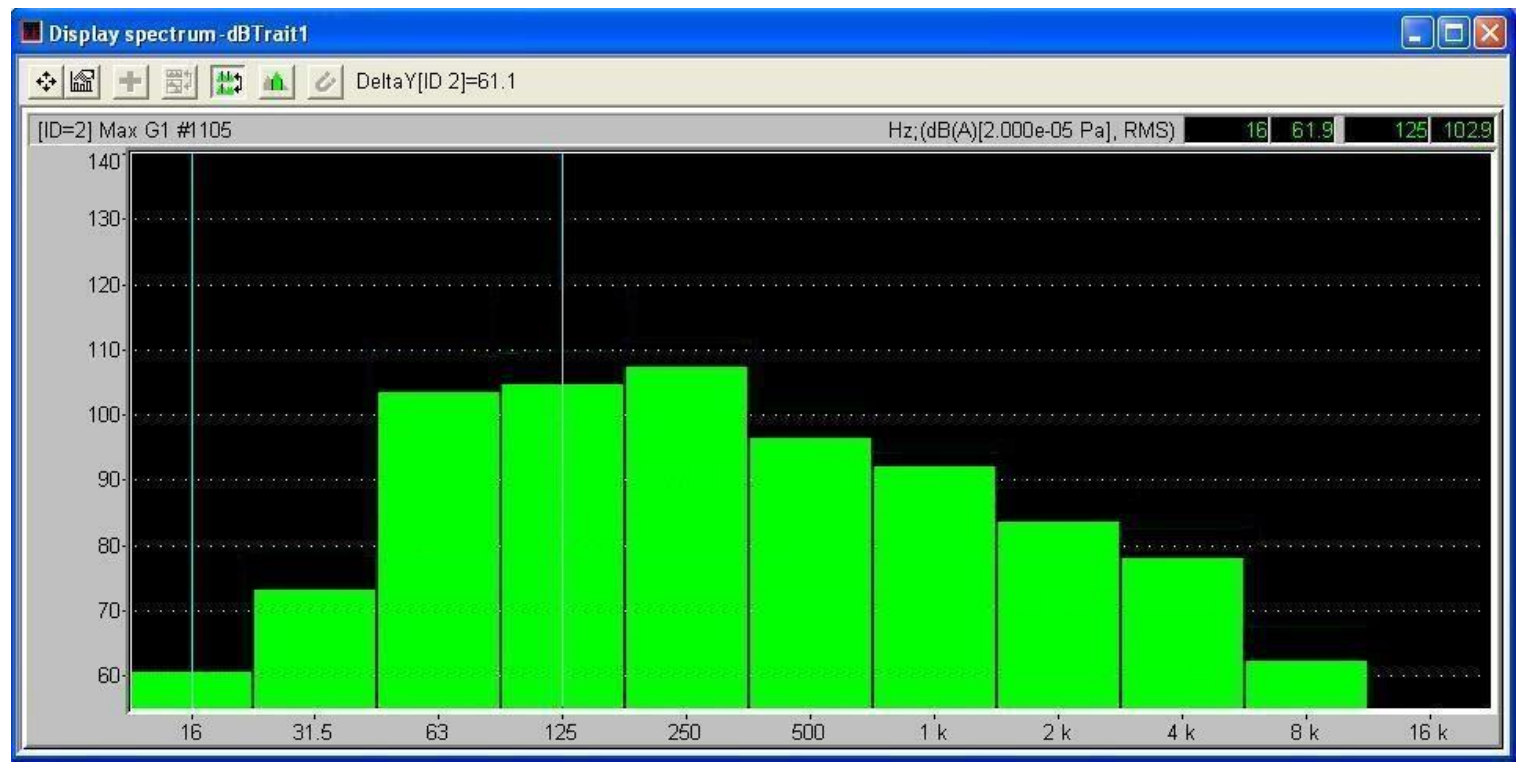

Fig. 4. Evaluation of noise in the engine room while ship is running

From Fig. 2 it is found that at the frequency of $16 \mathrm{~Hz}$, the sound level is $71.2 \mathrm{~dB}$, and at the frequency of $125 \mathrm{~Hz}$, the sound level is $92.3 \mathrm{~dB}$. The minimum reached is $63.4 \mathrm{~dB}$ at $8 \mathrm{kHz}$ and the maximum reached is $99.8 \mathrm{~dB}$ at $63 \mathrm{~Hz}$. From Fig. 3 it is found that at the frequency of $16 \mathrm{~Hz}$, the sound level is $63.2 \mathrm{~dB}$, and at the frequency of $125 \mathrm{~Hz}$, the sound level is $97.3 \mathrm{~dB}$. The minimum reached is $61.4 \mathrm{~dB}$ at $8 \mathrm{kHz}$, and the maximum reached is $97.5 \mathrm{~dB}$ at $250 \mathrm{~Hz}$. From Fig. 4 it is found that at the frequency of $16 \mathrm{~Hz}$, the sound level is $60.2 \mathrm{~dB}$, and at the frequency of $125 \mathrm{~Hz}$, the sound level is $103.3 \mathrm{~dB}$. The minimum reached is $60.2 \mathrm{~dB}$ at $16 \mathrm{~Hz}$, and the maximum reached is $107.8 \mathrm{~dB}$ at $250 \mathrm{~Hz}$.

It is observed that the maxima are obtained for two of the frequencies of the third octave analysed:

- $\quad$ for frequency $63 \mathrm{~Hz} \Rightarrow$ Maximum sound level $=99.8 \mathrm{~dB}$,

- $\quad$ for frequency $250 \mathrm{~Hz} \Rightarrow$ Maximum sound level $=97.5 \mathrm{~dB}$ and $107.8 \mathrm{~dB}$.

Calculating the Daily noise exposure $\left(L_{E P, d}\right)$ : Exposure points and Exposure points per hour with Exposure Calculator, the following results are obtained, if the ship is running, for engine room (Fig. 5):

\begin{tabular}{|c|c|c|c|c|c|}
\hline \multirow[t]{10}{*}{$\underset{\substack{\text { Health \& Safety } \\
\text { Executive }}}{\overline{\overline{\mathrm{H}} \mathbf{\mathrm { E }}}}$} & Exposure Calculator & $\begin{array}{c}\text { Noise Level } \\
\left(L_{\text {Aeq }} \text { dB }\right)\end{array}$ & $\begin{array}{c}\text { Exposure } \\
\text { duration } \\
\text { (hours) }\end{array}$ & $\begin{array}{c}\text { Exposure } \\
\text { points } \\
\text { (job/task) }\end{array}$ & $\begin{array}{c}\text { Exposure } \\
\text { points per } \\
\text { hour }\end{array}$ \\
\hline & Job / task 1 & 102 & 1 & 626 & 626 \\
\hline & Job / task 2 & 110 & 1 & 3953 & 3953 \\
\hline & Job / task 3 & 108 & 1 & 2494 & 2494 \\
\hline & Job / task 4 & 109 & 1 & 3140 & 3140 \\
\hline & Job / task 5 & 112 & 1 & 6265 & 6265 \\
\hline & Job / task 6 & 108 & 1 & 2494 & 2494 \\
\hline & Job / task 7 & 104 & 1 & 993 & 993 \\
\hline & Job / task 8 & 105 & 1 & 1250 & 1250 \\
\hline & \multicolumn{2}{|c|}{ Daily noise exposure $\left(L_{E P, d}\right)$} & $108 \mathrm{~dB}$ & \multicolumn{2}{|c|}{21215 points } \\
\hline
\end{tabular}

Fig. 5. Daily noise exposure ( $\left.L_{E P, d}\right)$, Exposure points (job/task) and Exposure points per hour (engine room, running ship) 


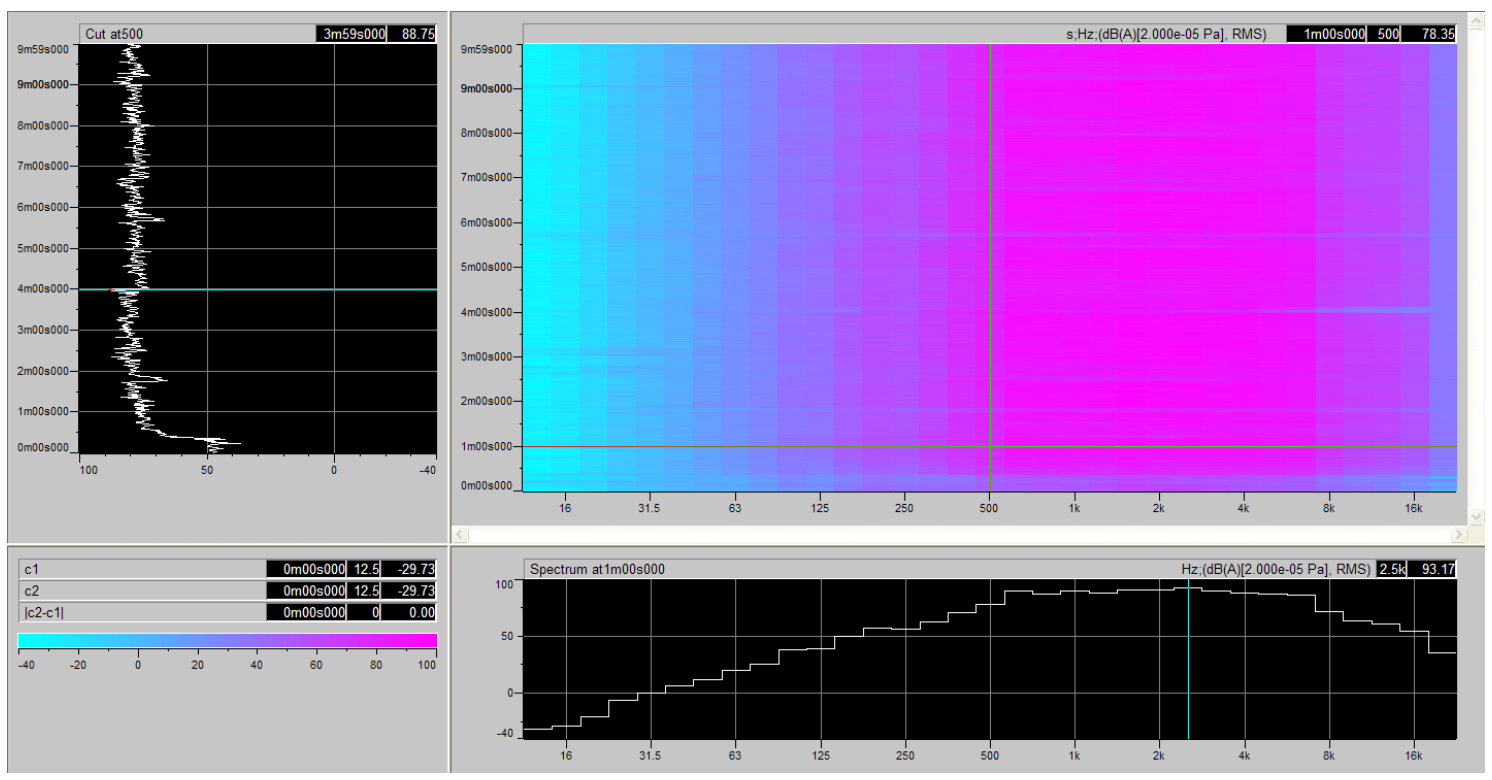

Fig. 6. Sonogram of the noise measured in the control cabin when the ship leaves the shore

\subsection{Measurements inside the command room}

Inside the command room determinations were made for the captain and the coxswain three cases: the ship leaves the shore, the ship is running, and mooring. Frequency-based noise analyses, for each case, are shown in Figs. 6-8.

Fig. 6 is the sonogram of the noise measured in the control cabin when the ship leaves the shore (top right). Cursors are placed at $500 \mathrm{~Hz}$ and 1 minute $(78.35 \mathrm{~dB}(\mathrm{~A}))$. At 1 minute, the frequency spectrum diagram (bottom right) shows a maximum of $93.17 \mathrm{~dB}(\mathrm{~A})$ at $2500 \mathrm{~Hz}$. The sound level Leq has a maximum of $88.75 \mathrm{~dB}(\mathrm{~A})$, at $3 \mathrm{~min} .59 \mathrm{sec}$. in the timeline presentation (top left) for $500 \mathrm{~Hz}$.

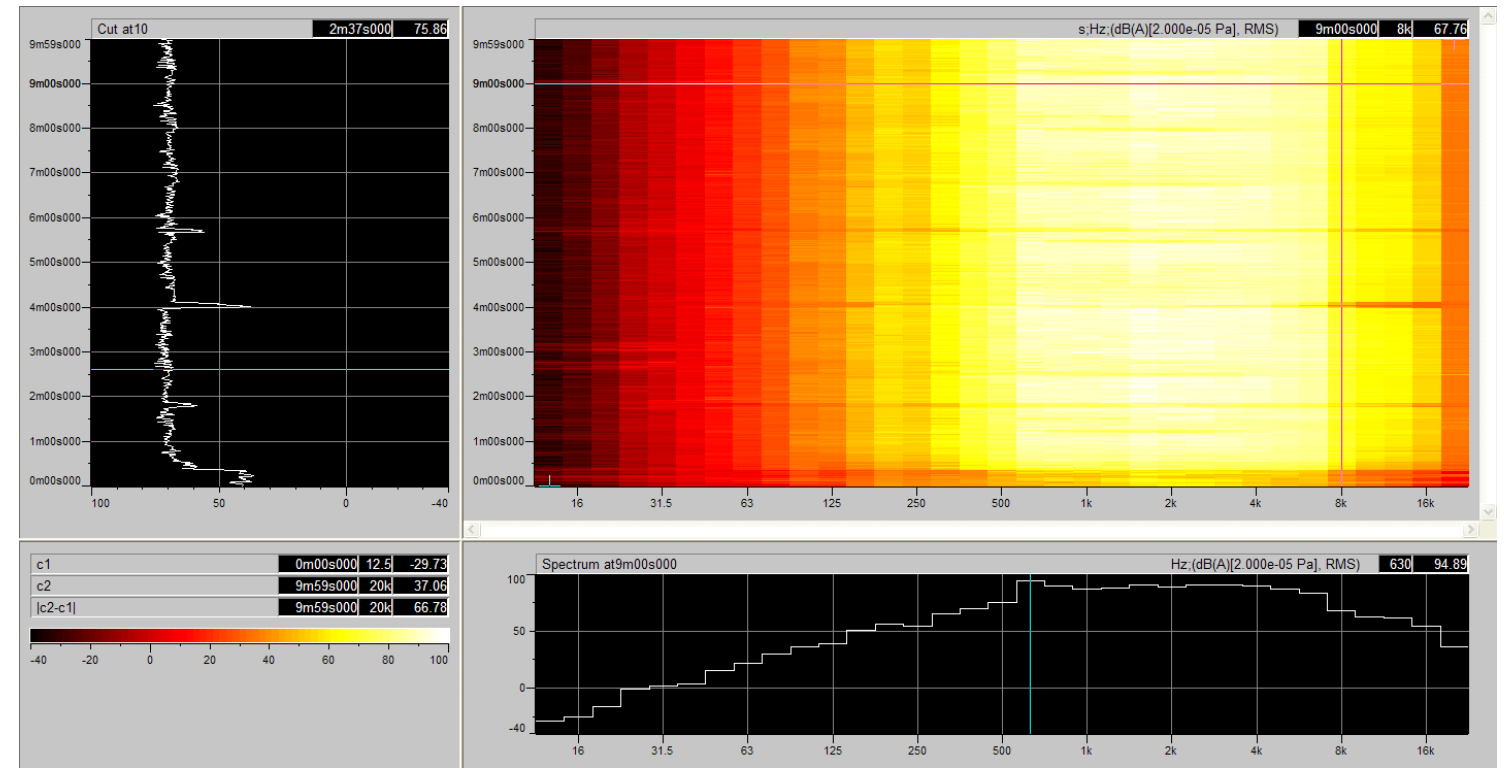

Fig. 7 Sonogram of the noise measured in the control cabin for the mooring manoeuvre

Fig. 7. is the sonogram of the noise measured in the control cabin for the mooring manoeuvre (top right). Cursors are placed at $8 \mathrm{kHz}$ and 9 minutes $(67.76 \mathrm{~dB}(\mathrm{~A}))$. At minute 9 , the frequency 
spectrum diagram (bottom right) shows a maximum of $94.89 \mathrm{~dB}(\mathrm{~A})$ at $630 \mathrm{~Hz}$. The sound level Leq has a maximum of $75.86 \mathrm{~dB}(\mathrm{~A})$, at $2 \mathrm{~min} .37 \mathrm{sec}$. in the timeline presentation (top left) for $8 \mathrm{kHz}$.

Fig. 8 is the sonogram of the noise measured in the control cabin while the ship is running (top right). Cursors are placed at $1 \mathrm{kHz}$ and 7 minutes $(75.3 \mathrm{~dB}(\mathrm{~A}))$. The sound level Leq has a maximum of $79.3 \mathrm{~dB}(\mathrm{~A})$, at $3 \mathrm{~min} .29 \mathrm{sec}$. in the timeline presentation (top left) for $1000 \mathrm{~Hz}$. At minute 7 the frequency spectrum diagram (bottom right) shows a maximum of $77.48 \mathrm{~dB}$ (A) at $1600 \mathrm{~Hz}$.

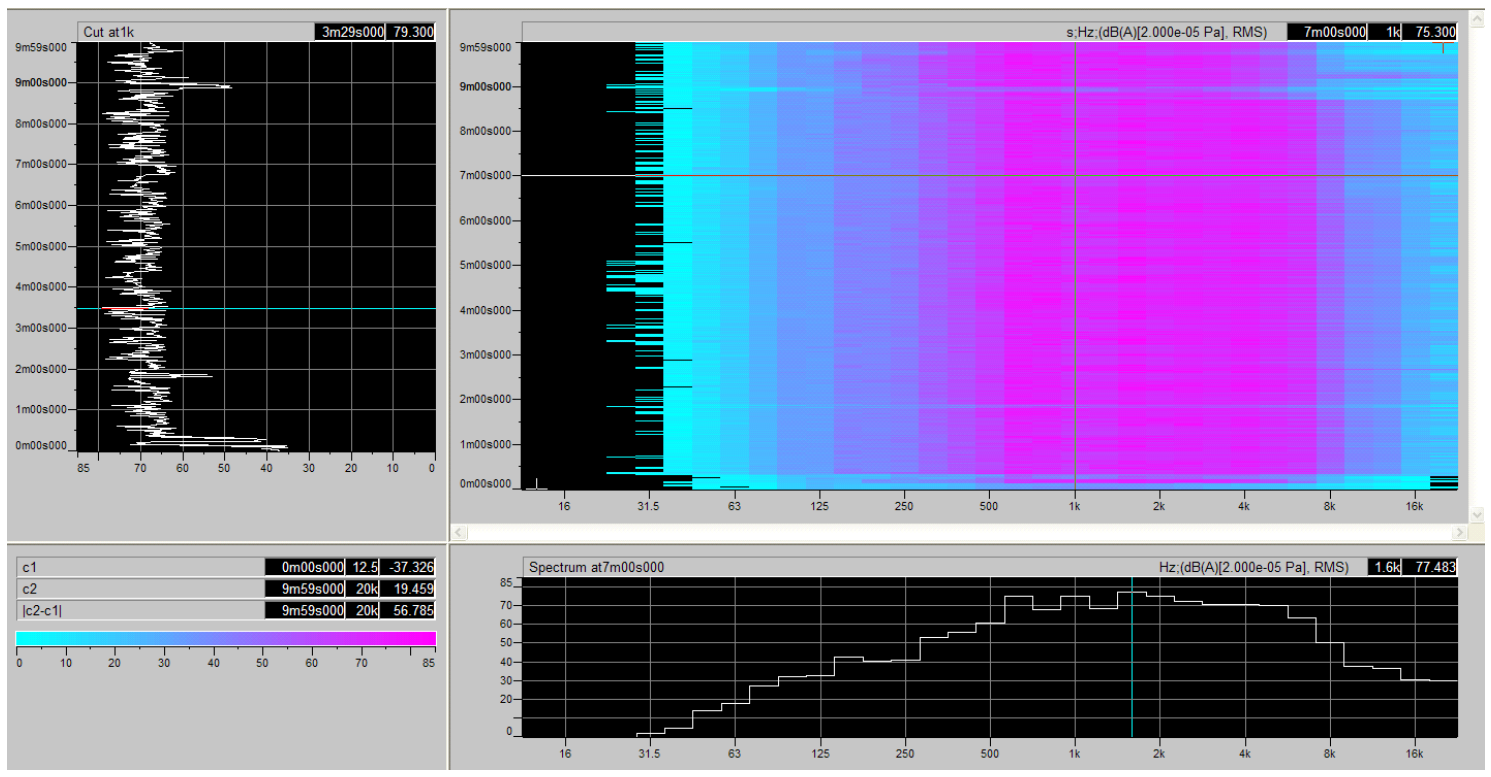

Fig. 8. Sonogram of the noise measured in the control cabin while the ship is running

Calculating Daily noise exposure $\left(L_{E P, d}\right)$ : Exposure points and Exposure points/hour with Exposure Calculator, the following results are obtained, when the ship is running inside the command room (Fig. 9):

\begin{tabular}{|c|c|c|c|c|c|}
\hline \multirow[t]{10}{*}{$\mid \begin{array}{c}\overline{\bar{Z}} \mathbf{\overline { E }} \\
\begin{array}{c}\text { Health \& S Safety } \\
\text { Executive }\end{array} \\
\end{array}$} & Exposure Calculator & $\begin{array}{l}\text { Noise Level } \\
\left(\mathrm{L}_{\text {Aeq }} \mathrm{dB}\right)\end{array}$ & $\begin{array}{c}\text { Exposure } \\
\text { duration } \\
\text { (hours) }\end{array}$ & $\begin{array}{c}\text { Exposure } \\
\text { points } \\
\text { (job/task) }\end{array}$ & $\begin{array}{c}\text { Exposure } \\
\text { points per } \\
\text { hour }\end{array}$ \\
\hline & Job / task 1 & 82 & 1 & 6 & 6 \\
\hline & Job / task 2 & 75 & 1 & 1 & 1 \\
\hline & Job / task 3 & 76 & 1 & 2 & 2 \\
\hline & Job / task 4 & 81 & 1 & 5 & 5 \\
\hline & Job / task 5 & 80 & 1 & 4 & 4 \\
\hline & Job / task 6 & 77 & 1 & 2 & 2 \\
\hline & Job / task 7 & 79 & 1 & 3 & 3 \\
\hline & Job / task 8 & 79 & 1 & 3 & 3 \\
\hline & \multicolumn{2}{|c|}{ Daily noise exposure $\left(\mathrm{L}_{\mathrm{EP}, \mathrm{d}}\right)$} & $79 \mathrm{~dB}$ & \multicolumn{2}{|l|}{26 points } \\
\hline
\end{tabular}

Fig. 9. Daily noise exposure $\left(L_{E P, d}\right)$, Exposure points (job/task) and Exposure points per hour (command room, running ship)

Comparing the maximum sound levels of a day with activity and what is provided in Directive 2003/10/EC [1], it is found that the values recorded in the engine room far exceed the legal provisions, while the values measured in the control room are below the limits provided by the Directive (Fig. 10). 


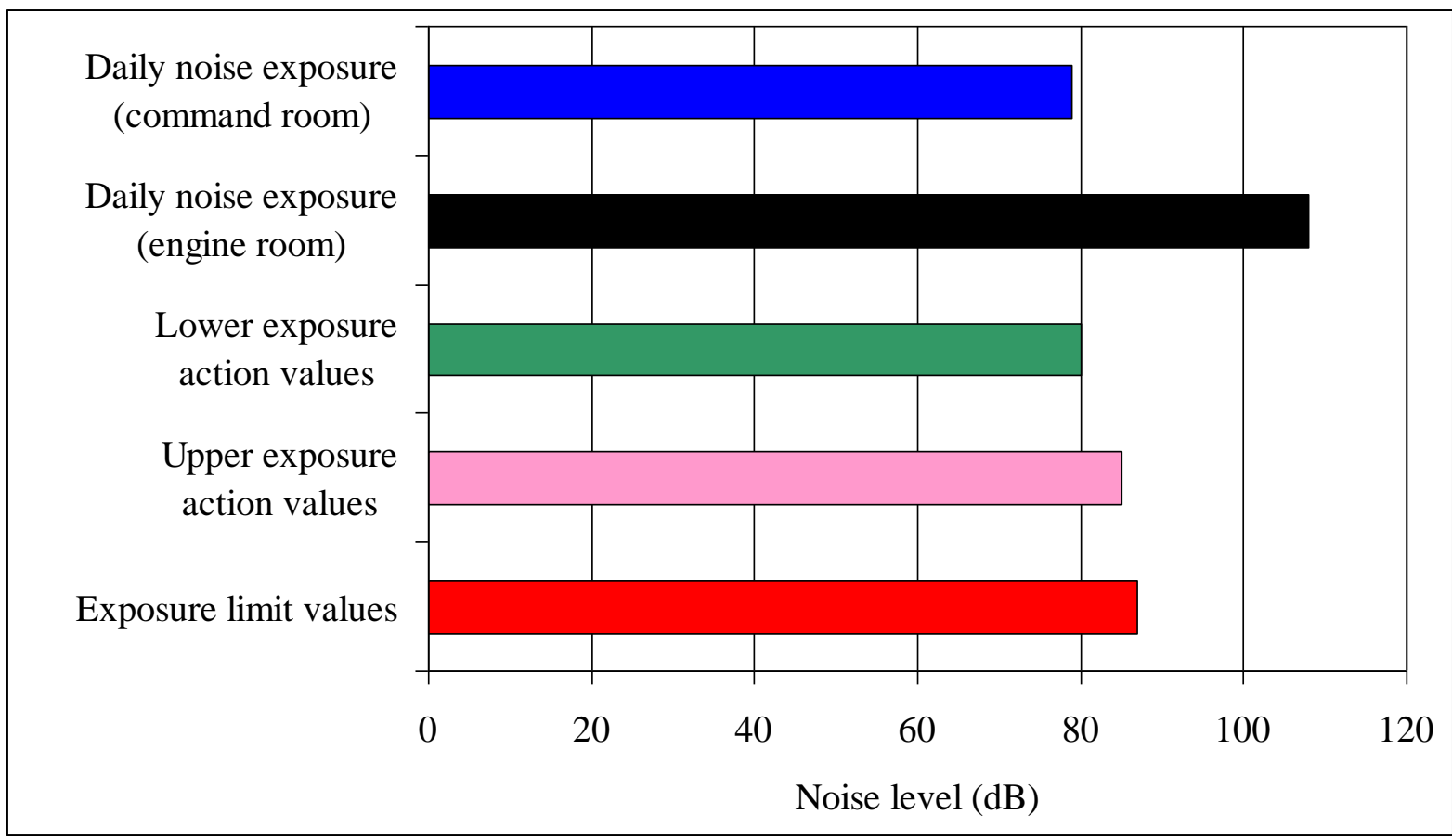

Fig. 10. Comparison between the sound levels provided by Directive 2003/10/EC and those measured in the engine room and control room

\section{CONCLUSIONS}

Figures 5 and 9 show the Daily noise exposure $\left(L_{\mathrm{EP}}\right.$, d), as well as the total Exposure points: inside the command room, Exposure points are 26 points; in the engine room, it is 21215 points namely 800 times higher, while the Lower Exposure Action Value is represented by 32 exposure points and the Upper Exposure Action Value by 100 points.

Table 2. Risk factor with the rise in $3 \mathrm{~dB}(\mathrm{~A})$

\begin{tabular}{|c|c|}
\hline $\mathrm{dB}(\mathrm{A})$ & Risk factor \\
\hline 100 & $\mathrm{x} 10$ \\
\hline 99 & $\mathrm{x} 8$ \\
\hline 96 & $\mathrm{x} \mathrm{4}$ \\
\hline 93 & $\mathrm{x} \mathrm{2}$ \\
\hline 90 & $\mathrm{x} \mathrm{1}$ \\
\hline 80 & $\mathrm{x} 0,1$ \\
\hline
\end{tabular}

This is better represented in Fig. 10, where it can be seen that the black column corresponding to the sound level in the engine room is $24 \%$ higher than the exposure limit values $(87 \mathrm{~dB})$. "For every rise in $3 \mathrm{~dB}(\mathrm{~A})$ the noise energy doubles and hence the risk factor does the same. In other words, someone working at $93 \mathrm{~dB}(\mathrm{~A})$ has doubled his or her risk of noise induced hearing loss over someone working at $90 \mathrm{~dB}(\mathrm{~A})$. By the same method, someone working at $80 \mathrm{~dB}(\mathrm{~A})$ has a tenth of the risk as someone working at $90 \mathrm{~dB}(\mathrm{~A}) . "$ (Table 2) [14].

For the health of those who work "under the deck", it is necessary to prompt the use of sound-absorbing materials or invest in the purchase of new ships.

\section{References}

1. DIRECTIVE 2003/10/EC OF THE EUROPEAN PARLIAMENT AND OF THE COUNCIL of 6 February 2003 on the minimum health and safety requirements regarding the exposure of workers to the risks arising from physical agents (noise), https://eur-lex.europa.eu/legalcontent/EN/TXT/PDF/?uri=CELEX:32003L0010\&from=ro

2. DIRECTIVE 2002/59/EC OF THE EUROPEAN PARLIAMENT AND OF THE COUNCIL of 27 June 2002 establishing a Community vessel traffic monitoring and information system and repealing Council Directive 93/75/EEC, https://eur-lex.europa.eu/legalcontent/EN/TXT/?uri=CELEX\%3A32002L0059. 
3. Hotarâre nr. 493 din 12.04.2006 privind cerintele minime de securitate si sanatate referitoare la expunerea lucratorilor la riscurile generate de zgomot Publicat in Monitorul Oficial, Partea I nr. 380 din 03/05/2006

https://www.ilo.org/dyn/natlex/docs/ELECTRONIC/99485/118781/F701091560/ROU99485.pdf.

4. DIRECTIVE 2009/17/EC OF THE EUROPEAN PARLIAMENT AND OF THE COUNCIL of 23 April 2009 amending Directive 2002/59/EC establishing a Community vessel traffic monitoring and information system, https://eur-lex.europa.eu/legalcontent/EN/ALL/?uri=CELEX\%3A32009L0017.

5. REZOLUȚIA MSC.337(91) din 30 octombrie 2012 Adoptarea Codului privind nivelurile de zgomot la bordul navelor, EMITENT: ORGANIZAŢIA MARITIMĂ INTERNAȚIONALĂ, Publicat în MONITORUL OFICIAL nr. 400 din 30 mai 2014, http://legislatie.just.ro/Public/DetaliiDocumentAfis/158681.

6. EUROPEAN COMMISSION, Guidelines on protection of health, repatriation and travel arrangements for seafarers, passengers and other persons on board ships, Brussels, 8.4.2020, http://www.imo.org/en/MediaCentre/HotTopics/Documents/EC\%20guidelines-protectionhealth-repatriation-_seafarers-passengers_08\%2004\%202020\%202342689.pdf.

7. Picu L., Picu M., Rusu E.V.C., An Investigation into the Health Risks Associated with the Noise and Vibrations on Board of a Boat - A Case Study on the Danube River, Journal of Marine Science and Engineering (JMSE), 7(8), pp 1-15, 2019.

8. Picu L., Rusu E.V.C., Picu M., An analysis of the noise in the engine room - case study a merchant ship navigating on Danube, Proceedings of the $19^{\text {th }}$ International Multidisciplinary Scientific GeoConference (SGEM 2019), Albena, Bulgaria, 19(5.2), pp 69-76, 2019.

9. DIRECTIVE OF THE EUROPEAN PARLIAMENT AND OF THE COUNCIL of 12 December 2006 laying down technical requirements for inland waterway vessels and repealing Council Directive 82/714/EEC(2006/87/EC), Official Journal of the European Communities https://eur-lex.europa.eu/legal-content/EN/TXT/?uri=CELEX\%3A32006L0087.

10. DIRECTIVE (EU) 2016/1629 OF THE EUROPEAN PARLIAMENT AND OF THE COUNCIL of 14 September 2016 laying down technical requirements for inland waterway vessels, amending Directive 2009/100/EC and repealing Directive 2006/87/EC https://eurlex.europa.eu/legal-content/EN/TXT/PDF/?uri=CELEX:02006L0087-20130110\&from=RO.

11. Comitetul european pentru elaborarea de standarde privind navigația interioară (CESNI) Ediția 2017/1-Standardul european de stabilire a cerințelor tehnice pentru navele de navigație interioară (ES-TRIN)

(https://www.cesni.eu/wp-content/uploads/2019/05/2017_01_RO_unoff_v.pdf).

12. Proiectul de ORDIN al ministrului transporturilor pentru aprobarea cerinţelor tehnice pentru navele de navigaţie interioară / 22.08.2018, Ministerul Transportului, Infrastructurii și Comunicațiilor (http://www.mt.gov.ro/web14/transparenta-decizionala/consultarepublica/acte-normative-in-avizare/2082-omt22082018dtn-2).

13. IEC 61672-1:2002, Electroacoustics - Sound level meters - Part 1: Specifications

14. Neitzel R., Determination of risk of noise-induced hearing loss due to recreational sound: review, World Health Organization, 2017,

https://www.who.int/pbd/deafness/Monograph_on_determination_of_risk_of_HL_due_to_exp osure_to_recreational_sounds.pdf. 